resolution passed at the Quarterly Business meeting of the Royal College of Psychiatrists, 20 November 1981, had been proposed by Dr P. Sainsbury and seconded by Dr G. Low Beer.

“... this General Assembly resolves that the withdrawal of the membership of the All-Union Society of Neurologists and Psychiatrists of the World Psychiatric Association should now take place until such time as... to an end."

Professor Rawnsley announced that the World Psychiatric Association had informed the Royal College of Psychiatrists that the All-Union Society of Psychiatrists of the USSR had resigned from membership of the World
Psychiatric Association. The All-Union Society had written to all member societies of the World Psychiatric Association and the College was awaiting this letter. Since the resolution in 1981, the College had received communications and a visit from the Russian Embassy as well as an unconfirmed invitation to take part in a multi-national delegation to visit the USSR.

Dr P. Sainsbury and Dr G. Low Beer expressed their regret at the decision of the Russian psychiatrists. It was hoped that in a few years the situation might ameloriate and channels of communication would be re-opened. In the meantime the Special (Political Abuse of Psychiatry) Committee should endeavour to envisage ways in which pressure could be maintained on the Soviet Union.

\title{
Reports from the Divisions
}

\section{Welsh Division}

The Welsh Division held two meetings in the course of 1982. The Spring Meeting was held at Cefn Coed Hospital, Swansea, on 3 April.

The morning programme was provided by members of the consultant staff of Cefn Coed Hospital. Dr T. G. Davies spoke on 'Bedlam in Wales'-a history of the evolution of Psychiatric Services in South Wales in the 19th century. Dr Gareth Hughes, in 'The Self-Poisoners of Aqua Sulis', presented a study of overdosage in the City of Bath, relating the incidence of self-poisoning to a variety of social parameters.

In the afternoon papers were presented by members of the Postgraduate Section and the Section of Mental Subnormality. In the first Dr Marshall Annear (Morgannwg Hospital) reviewed the development of Postgraduate Education in Wales, while in the second, Dr W. B. Spry (Garth Angharad Hospital) presented a paper on recent developments at that hospital.

At its Biannual General Meeting, the Chairman of the Division for the past two years, Dr J. Cuthill (Morgannwg Hospital), relinquished office and Dr J. M. Hughes (St Cadoc's Hospital) took over, thanking the retiring Chairman and Secretary (Dr A. Kellam) for their work for the College in Wales.

In the evening the Welsh Division Dinner was held at College House, University College, Swansea. Professor Rawnsley was formally congratulated by the Division on his election as President and received new Members and Fellows.

The Autumn Meeting was held at St Cadoc's Hospital, Caerleon, on 4 December. Dr Brian Calcraft (Royal Gwent Hospital) spoke on the 'Irritable Bowel Syndrome' and Dr Delyth Alldrick (St Cadoc's Hospital) presented a paper on 'Aspects of Liaison Psychiatry'.
The Psychotherapy and Child Psychiatry Sections contributed to the afternoon programme. Dr Ronald Westerholm spoke on the work of a Psychotherapy Unit at Cefn Coed Hospital, while Dr G. S. Thomas (St Cadoc's Hospital) reviewed the literature on dysmorphophobia and summarized the management of adolescents who had presented to the Adolescent Unit with such a picture.

The Executive Committee met quarterly throughtout the year and reported to the Welsh Office on the following: the review of ECT treatment in Wales; comments on Care in the Community; matters of concern in regard to the Mental Health (Amendment) Act proposals; breaches of confidentiality in an HAS Report; and the proposals for Services for the Mentally Handicapped in Wales.

Dr Cuthill was nominated by the Welsh Division and appointed by the Council as Regional Psychiatrist in place of Professor Rawnsley. Dr E. Kapp retired from the Editorship of the College's 'Welsh Newsletter' and Dr Gareth Jones took over.

The Welsh Postgraduate Committee (following pressure from the Executive and the Postgraduate Section in Wales) agreed to recognize a Working Party of Clinical Tutors in Psychiatry.

A. B. Rolfe

Honorary Secretary

\section{Midlands Division}

The Spring Meeting of the Midlands Division took place at the Education Centre and Main Hall at Hollymoor Hospital, Birmingham on 18 March 1983.

Professor C. P. Seager (Chairman) opened the scientific session, which was attended by 250 delegates. He introduced Professor R. Bluglass who gave a talk entitled 'The Mental 